\title{
The Extent to Which Resource Room Teachers Making Use of Visual Organizations to Teach Students with Learning Disabilities
}

\author{
Mohammad Kh. M. Muflih ${ }^{1}$ \\ ${ }^{1}$ Jordan University of Science and Technology, Irbid, Jordan \\ Correspondence: Mohammad Kh. M. Muflih, Jordan University of Science and Technology, Irbid, Jordan.
}

Received: July 30, 2018

Accepted: September 11, 2018

Online Published: November 27, 2018

doi:10.5539/ies.v11n12p12

URL: https://doi.org/10.5539/ies.v11n12p12

\begin{abstract}
This study aimed at revealing the reality of teacher's use of learning resources rooms of graphic organizers in teaching students with learning disabilities, and the difficulties the teachers face while teaching these students. The study sample consisted of 83 of resource room teachers in Irbid Directorates of Education schools, to achieve the goals of the study, a questionnaire of 28 items was developed; 16 were used to reveal the reality of teachers' use of learning resources, 12 items were used to reveal the difficulties that limit the teachers' use of learning resource rooms of graphic organizers. The study also attempted to find the effect of certain variables such as gender, scientific qualifications and years of experiences on the teachers' use of learning resource rooms of graphic organizers in teaching students with learning disabilities. The results of the study revealed the following: 1) In terms of the use of graphic organizers, the average of the means was 2.13 with a low level, and in the terms of difficulties, the average of the means was 2.77 with a high level. 2) There were significant differences among the means due to gender and in favor of males; due to level of qualifications and in favor of high diploma and, master degree; and due to years of teaching experiences and in favor of those who taught more than 10 years. The study reported certain recommendations for professionals and researchers.
\end{abstract}

Keywords: teachers of resource rooms, graphic organizers, students with learning disabilities

\section{Introduction}

Science seeks the happiness of the individual, the educated person feels the value of the knowledge he possesses and tries to apply it in his field of work and daily life, education raises the social status of the person, changing his social status and making him an individual with a prominent goal in this life. From this point of view, the recommendations of the National Conference for Educational Development, which took place in Amman (teacher's letter, 1987), which was a comprehensive review of the educational process in all its dimensions, education is the right of everyone not only for gifted and ordinary students, but also for students with learning disabilities who have significant learning difficulties stemming from within the individual, accompanied by problems of social behavior. The difficulty is compounded by the fact that it is hidden difficulties. Therefore, this student is unable to walk at the level of his ordinary colleagues; this is illustrated by the criterion of discrepancy between the expected achievement of the child in light of his mental abilities and his actual achievement (Waqfi, 2009).

A team of educators emphasizes the need to create a learning environment that contributes to raising the level of students with learning disabilities from the school and students in the basic grades 2 to 6 by enrolling them in special rooms within the school to provide educational services in an educational program running parallel to the school program, and depends on the educational plans that meet their needs and in a special place called "Resource Room", ranging from (30-48 square meters) and equipped with furniture, educational means and educational games required (Batayneh, 2007).

Great responsibility has been thrown on the shoulders of teachers after qualifying and enrolling them in educational programs or training courses on learning difficulties - by modifying the methods used and diversifying the teaching strategies used in resource rooms to help students with learning disabilities to create a useful memory that helps them to retrieve flexible information and achievement (Al Qasem, 2012).

The formation of useful memory for students of learning disability is still a difficult task as there is not yet a specific method that motivates students to learn and overcome the problem of ordering and organization of ideas 
only in the provision of teaching content using practical teaching strategies in tune with the meaningful learning theory proposed by the American psychologist Ausubel (1993), where it includes a "practical" model, the graphic organizers model developed by Novak and Gowin (1984). It revolves around the concept of meaningful learning that occurs when storing new information in a hierarchical way from general to specific, and thus facilitate their learning and retrieval easily by the extent to which new information is linked to previous information and organized within the Cognitive construction (Al Farhan, 2008).

The activation of the student's previous learning is a fundamental process in all types of learning, and that his knowledge backgrounds will be influential on what he will understand in all kinds of new learning; if the learner began with an accurate previous knowledge, and the new material is understandable and consistent with the student's cognitive construction, meaningful learning can be achieved by linking new learning with the ideas that exist in the previous cognitive construction, especially if this structure is systematic, clear, consistent and related to the new material because it deepens the learner's ability to retain and retrieve the material (Badawi, 2004).

The use of visual organizations by the teachers of the resource rooms helps to organize the ideas and meanings contained in the unit by organizing the knowledge of students with learning disabilities and deepening their understanding of the subject material, as it reflects the visual logical, psychological and cognitive structure, and includes a series of popular steps In which knowledge is abstracted from its linear form to hierarchical, which means that the most comprehensive concepts come at the top of the map and branch out of concepts and issues that are less comprehensive and more specific (Attia, 2008).

A student who is aware of the curricula and textbooks of basic stage students finds that visual organizations are rarely used as teaching strategies that contribute to the learning of students, especially students with learning disabilities. Robert (2006) explains how to build a visual map, the teacher introduces the students with learning disabilities to the process of visual mapping-as something new-gradually, it is preferable to define the concept that he wants to teach students such as the movement of letters, and then works to build a visual map for him with the specifications he wants and it is preferably that the concept to be from the environment of the students and familiar to them, and also it is preferable to put limited spaces in the map and put a key and add words or keywords to help students fill in the map spaces and answer the required. The importance of visual organizations to students with learning disabilities in that it helps them to clarify ideas and image content and provide concepts in the form of drawings or images that enable them to link them easily, and the formation of concepts and sensory and mental images and then read or understand the symbols and verbal words, and this helps them to understand and comprehend the educational content due to the fact that visual organizations is a form "a language of educational communication" (Dwyer, 1994).

It can be said that visual organizations help to build the right concept and strengthen students to be more aware of the appropriate strategy and select the appropriate method that helps them to gain the right learning and keep the information easier and longer (Ellis, 2001).

Students at all age levels can benefit from visual organizations in subjects and in various fields (Dye, 2000), students with learning disabilities need strategies to help them achieve success, raise their academic level, focus on important information, and how to organize this information, they need to interact with each other, facilitate teamwork among themselves, and strengthen their attitudes and motivation. All this can be achieved with visual organizations that help students understand content, organize information, and keep it in mind when needed, making it easier for students to learn and help them understand content, information organization, retention and call-up when needed.

Al-Waqfi (1996) points out that the visual organizations are a successful and effective way to raise the level of achievement among students with learning disabilities. It is also mentioned that these visual organizations help the resource room teacher in:

- Planning for teaching whether for a lesson, unit, semester, or a year

- Concentrate the attention of learners, and guide them to the way they organize their ideas and discoveries.

- Select the appropriate activities and learning aids.

- Evaluating the students 'understanding and understanding of the structural construct of the course material. Exploring students' misconceptions and working to correct them.

- Enabling students to master concepts related to the materials or courses they are studying.

- To develop the spirit of cooperation and mutual respect between him and his students.

- Provide a collective learning environment for discussion among learners. 
- Measuring the change and development of concepts among learners

Principles of Using Visual Organizations:

Numerous educational applications emerged from the ideas of the Ausubel's theory of meaningful learning in the creation of many educational tools, including many forms of visual organizations.

There are four principles of meaningful learning theories that call for the use of visual organizations (Oleary, 1995):

1) Focus on basic information and separate marginal information.

2) Organize and store information in an orderly manner.

3) Provide information through a visual organizer that contains key ideas to facilitate learning.

4) Use spoken language and visual language to form visual organizations that lead to active and effective learning (Attia, 2008).

Forms of visual organizations:

Visual organizations are often classified under four forms so that each form can be applied to each type of knowledge (Mernda, 2011).

1) Visual (schematic) conceptual organizations: such as the art forms organizer, bubble map, and comparison tables used to describe brands and objects, and used in comparisons between two themes

2) Hierarchical visual organizations: such as map concepts, tree map. Spider and Celtic are used for classification from the most general to the most private

3) Circular visual organizations and the hierarchical map are used to define and clarify an idea

4) Sequential visual organizations: such as cause and effect regulator, problem and solution.

5) Time line: used to illustrate the sequence or practical steps, in explaining the relationship between cause and effect and position analysis and are used to illustrate the simulations and relationships.

Visual mapping will be something new to students, so they should be presented to them gradually by the teacher. Ideally, the teacher will better define the concept he wants to teach to the students such as the letter movement, and then build a visual map of it with the specifications he wants. In the case of the elementary stage, it is preferable to have the concept from the students' environment and familiarity with them. It is also preferable to put limited spaces in the map and put a key to it and add key words or words that help students fill the spaces of the map and answer the required ones (Hyerle, 1995). The concepts can be presented in the form of drawings, images or forms that can be easily linked, thus preparing the students for the idea of the concept map, and may be exposed to concepts or events directly or in the form of written text.

The importance of the strategy of visual organizations:

Visual organizations as an instructional teaching strategy not only helps the learner to learn, but also teaches him how to learn what develops scientific skills and develop his thinking abilities, and is in line with many of the principles of learning, most notably the principle that knowledge is stored in order. Ausubel said that the learner understands the new concepts so that it integrates with the previous concepts related to them (Novak \& Gowin, 1984).

It is clear from the above that the use of the strategy of visual organizations by teachers is very important in the educational process because it may be one of the basic criteria that help students with learning difficulties to teach them how to learn and develop their mental skills, increase their ability to think and lead them to participate actively in the formation of a coherent cognitive construct integrated with a basic concept. It also helps to clarify the structure of the material in the form of a conceptual network that enables them to understand and absorb the material better which helps them to integrate and keep up with their colleagues from ordinary students in education. Visual organizations also help students with learning disabilities to meet the challenges they face when learning a particular subject, form relations between concepts, and learning how to learn, it reduces anxiety and shifts their attitudes towards difficult concepts.

Advanced organizations achieve the following benefits:

1) Facilitating the educational process for the teacher.

2) The teacher can transfer a large amount of information to learners.

3) Educate learners of the new topic and make it familiar to them. 
4) Advanced organizations develop at the learner the ability of inference and induction to understand relationships and connect information to be meaningful learning.

5) Advanced organizations enable learner to control the subject of learning and contribute to his cognitive development, so that he keeps the information and makes it interconnected with his cognitive construct, which develops his cognitive development (Zaghloul,2001)

\subsection{The Problem of the Study and its Questions}

Through the study of theoretical literature and previous studies of the problems faced by students with learning difficulties in regular schools, these studies did not address the strategy of teaching through the visual organizations although the child who has learning difficulties is a child with the average or above average or higher intelligence and is more aware of his failure at school and is more sensitive to the implications of this on the home, This requires to respond to this group of students by providing practical teaching strategies that meet their needs as a teaching strategy with visual organizations (Balawi, 2014). Where it became clear to the researcher that the teachers' use of this strategy did not reach the required level or it is rarely used. According to the researcher's knowledge, there is no study in Arab or foreign studies tackles the reality of the use of visual organizations as a strategy in teaching which helps to classify the subject in a hierarchical way and less general concepts interrelate with more sub - concepts and works to embody abstract concepts and help students with learning disabilities to reach the best level of education to help them integrate with their fellow students in the rest stages at the school. Accordingly, this study was conducted to investigate the extent to which resource room teachers used visual organizations to teach students with learning disabilities and the obstacles that prevent teachers from using it. Hence the problem of the study that tries to answer the following:

1) What is the degree to which teachers of the learning resource rooms use visual organizations to teach students with learning disabilities?

2) What are the difficulties faced by resource room teachers in using visual organizations in resource rooms?

3) Are there any statistically significant differences $(\alpha=0.05)$ in the degree of using visual organizations in teaching students with learning disabilities due to gender, scientific qualification and years of experience variables?

\subsection{Objectives of the Study}

This study aimed to achieve the following:

- Identify the degree to which resource room teachers use visual organizations to teach students with learning disabilities.

- Identify obstacles that prevent the use of visual organizations in resource rooms.

- To detect differences in the degree of use of visual organizations in the teaching of students with learning disabilities according to gender, scientific qualification and teaching experience variables.

\subsection{Significance of the Study}

The importance of the study lies in the importance of the subject of the research and the availability of data and information about the needs of students with learning disabilities to teach them using strategies that reflect the information in a sensory way that will benefit the students when integrating them with their fellow students. In addition, in addition, the importance of the study will show the results that the researcher will reach if they are taken by the concerned authorities and turn them into teaching decisions and it also help decision-makers identify the strengths and weaknesses of the schools in which this category is merged with ordinary students.

\subsection{Procedural Definitions}

The study included the following terms:

Degree of use: The extent to which teachers use visual organizations to help students with learning disabilities draw a mental and auditory image that constitutes new information to become an integral part of the student's overall cognitive structure.

Students with Learning Disabilities: Students who were classified in the category of learning disabilities in the regular schools in the basic stage from the second to the fourth grades. They show deficits or delays in one or more pronunciation, language, reading, spelling, writing, or mathematic processes resulting from a possible disorder as an emotional or behavioral disorder but not a result of mental retardation, sensory disability, or cultural or educational factors. 
Visual organizations: A study material that provides a prelude to study before the students learn the new material in a hierarchical form, ranging from the most comprehensive and least private concepts at the top of the pyramid to the less comprehensive and more exclusive concepts at the base of the pyramid, these concepts are surrounded by frameworks that are related to each other by means of shares in which the type of relationship is written.

Resource Rooms: A hall of the school's teaching rooms contains specialized programs to ensure that students with learning disabilities are educated individually in a way that suits each student and his own characteristics, needs and abilities; they receive remedial education and related services outside the regular classroom for between $21 \%$ and $60 \%$ ) of the school day. It is equipped with the necessary educational equipment to help students with learning disabilities understand and use spoken or written language, the students of the source rooms are taught one period and return to the ordinary class for the rest of the school day according to the concept of integration into the regular classes.

Learning Disabilities Teacher: The Resource Room Teacher is a special education teacher specializing in learning disabilities and works in a special classroom (called a resource room) in a regular school. In this room, students with learning disabilities attending the regular class receive special educational services at specific times of the school day. The resource room works either according to a taxonomic approach (i.e. serving one disability category) or according to a non-taxonomic orientation (i.e. serving different disability categories). The equipment room often has special equipment and tools that are compatible with the desired functions.

\subsection{The Limits of the Study}

The study was limited to the following:

- The results of the study are determined by the responses of the study members to the questionnaire regarding the degree of use of the resource room teachers for the visual organizations.

- Objective Limits: To identify the degree to which resource room teachers use visual organizations to teach students with learning disabilities and obstacles to their use.

- Spatial Limits: Public schools in Irbid governorate, where educational resource rooms are available to teach students with learning disabilities within a remedial program designed for this purpose.

- Time Limits: The first and second semester of the academic year 2015-2016.

- Human Limits: Teachers of students with learning disabilities.

\section{Previous Studies}

Hussein and Ahmad (2016) conducted a study aimed at finding out the effect of the use of the visual organizations' strategy in the visual thinking skills of fourth grade students in chemistry. The sample consisted of (67) fourth grade students who were divided into two groups; experimental (34) and control (33), the two groups were equivalent in the variables: (previous information, the age in months and the previous year degrees in chemistry and mental abilities, and the visual thinking test), in order to achieve the objective of the study, an educational material was prepared according to the strategy of the visual organizations, and a test of the visual thinking skills specified with (shape recognition skill, shape analysis skill, interpersonal skills, Mystery in visual form, the skill of extracting meanings) Composed of (44), after the calculation of the psychometric characteristics of both tests, the data were statistically treated using SPSS. The results showed a statistically significant difference between the experimental group students who were taught using the strategy of the visual organizations and the control group students who were taught using the traditional method of visual thinking skills for the experimental group, Therefore, the researcher recommends adopting the strategy of visual organizations in the teaching of chemistry, and it is proposed to conduct other studies for different stages and subjects of study for their effect on visual thinking

Humbert (2014) study dealt with the use of visual organizations: concept maps and Venn's plan for the achievement of students in the fifth grade in reading. The sample included two classes of the fifth grade level and lasted for four weeks. The study provided reading texts for students to read it using the Venn diagram and conceptual maps. Examinations were conducted before and after the use of visual organizations. The research concluded that the use of two types of visual organizations: Venn's diagram and conceptual maps increased the results of student achievement.

Ives (2002) conducted a study aimed at the effectiveness of the use of advanced visual organizations for a sample of students with learning disabilities in mathematics due to problems of pronunciation, reading and attention. The aim of the research was to find out the impact of teaching using advanced organizations in understanding complex mathematical formulas for students with learning disabilities. The research was conducted on two groups of 
students: the first used the traditional method and the second group was taught using advanced visual organizations. The researcher concluded that students who studied through visual organizations were able to understand mathematical concepts and methods of solving and linear equations more than students who were taught mathematics in the usual way.

The study of Chen (2001) tackled short-term and long-term effects on the use of two types of advanced organizations: conceptual maps and a text outline. The study included students of health ethics through the Internet and two practical and theoretical tests were conducted for (166) undergraduate students, consisting of control group and two experimental groups, advanced organizations were used for one week, each group used a specific type of advanced organizations. There were a pre and post exams and then a questionnaire and interviews. The study showed the following results: The effects are positive for the short-term achievement of the students who studied through the conceptual maps. The results of the study showed that the use of advanced organizations and their different types have positive effects for students with learning disabilities.

Shareef (2011) conducted a study aimed to know the effect of the use of concept maps on achievement and adjustment of attention deficit in special education students, the sample of the research was limited to fourth grade students in special education in the center of Nineveh governorate for the year 2010-2011. The sample consisted of (18) students divided into two groups: (8) students in the experimental group studied using conceptual maps and (10) students in the control group studied in the ordinary way, the results showed that there were statistically significant differences in the achievement between the two groups, in favor of the experimental group, as well as an adjustment in the lack of attention for the benefit of the experimental group. The study recommended the use of concept maps in the education of special education students and proposed conducting a similar study of the current study in the science course.

Balawi (2014) study aimed to investigate the effectiveness of a program based on illustrations in improving the level of reading comprehension skills among students with learning disabilities in a sample of students with learning disabilities in Saudi Arabia. The semi-experimental design was used. The study sample consisted of (40) students from the fourth grade level who were selected in an accessible manner, they were randomly distributed in two groups; experimental group that used illustrations to improve reading comprehension skills and control group that used in the normal method, then pretest was applied on control and experimental groups to ensure the equivalence of the sample of the study and its validity to conduct the study. The results showed that there were statistically significant differences in the improvement of the level of reading comprehension skills and for the benefit of the experimental group which was studied using a program based on illustrations.

Gardill and Asha (2004) conducted a study aimed at verifying the effectiveness of the illustration strategy in improving reading comprehension among a sample of students with learning disabilities. The study sample consisted of six students (grades 6,7 and 8) enrolled in the learning resource rooms, who were diagnosed with learning disabilities and weakness in the skill of reading comprehension. The students were trained in the strategy of story maps in direct and organized steps, where a map was designed for each story that was taught to the student, this map was designed to help the student to understand the implicit information in the text, to extract the ideas, to identify the characters, the problem, the solution, and the knowledge of the story details. The results of the study indicated the effectiveness of this method in improving the comprehension of students with learning disabilities, the researchers pointed out that this strategy provided the students with a "clear" framework for organizing and recalling the important elements of the story: characters, ideas and events, enriching their reading comprehension.

Miranda (2011) conducted a study one of its objectives was to identify the effect of the use of illustrations in improving the reading comprehension skills of a student of learning disabilities who suffer from reading difficulties. The study used the case study methodology where one of the students of learning difficulties was chosen with literacy difficulties, and then teaching some reading texts using illustrations, the reading comprehension skill of the student participating in the study was measured before and after the teaching of the reading texts using illustrations. The results indicated that the illustrations were an effective "instructional" program capable of improving reading comprehension skills in the student with learning difficulties.

Macarthur (2001) conducted a study aimed at identifying the extent to which teachers of students with learning disabilities use educational techniques while teaching students to read and write, and to identify their attitudes towards it, and how they benefit from it in their interactions with students and within the resource room. The study sample consisted of about $(1,000)$ teachers from Delaware state. The study reached the following results: teachers found that educational techniques are an effective tool in teaching students with reading and writing disabilities, and about (97\%) of teachers believe that educational techniques help students acquire literacy skills, recognize words, correct mistakes, and avoid falling into them. 
Al-Abed (2011) conducted a study aimed at identifying the satisfaction of the parents of students with learning disabilities about the services provided to them in the resource rooms in the city of Amman. The study sample consisted primarily of students with learning disabilities enrolled in the resource rooms in the Directorate of Amman, estimated at (2000) students. The results showed that the most satisfactory services for parents are the services provided by the resource room teacher followed by the classroom environment services for the source rooms, while the least satisfactory services for parents are the methodological services.

\subsection{Comments on Previous Studies}

This study is distinguished from the previous studies that came to reveal the reality of using resource room teachers for visual organizations in teaching students with learning difficulties in public schools in Jordan, while the previous studies were limited to the use of visual organizations on achievement and development of reading and writing in ordinary students and learning difficulties, Therefore, the current study is different from previous studies by addressing the reality of the use of resource room teachers for visual organizations. Therefore, the current study is considered the first within the scope of the researcher's knowledge, which will address the reality of the use of resource room teachers for the visual organizations in teaching students with learning difficulties, and the current study was interested in uncovering some of the difficulties that hinder the use of visual organizations in teaching students with learning difficulties, which strengthened the conduct of this study in the light of the variables that distinguish them from other previous studies.

The value added in this study is one of the educational strategies based on evidence in teaching students with learning disabilities through the selection of visual organizations that fit the curriculum.

The results of the previous studies showed that the use of the strategies of the visual organizations has a positive impact on the development of the cognitive construct and in increasing the achievement of students in general and those with learning disabilities, in particular, which reinforced conducting of this study.

\section{Study Methodology}

This study is one of the descriptive survey studies, the methods of scientific research were adopted in terms of the procedures of the study to collect data, analyze it, and draw conclusions and discussions.

\subsection{Sample of the Study}

The sample of the study included all the teachers of the resource rooms of both sexes in the public schools affiliated to the directorates of education in Irbid Governorate, their number was (83) teachers who were chosen purposefully, they are all the teachers who responded during the distribution of the tool after inquiring and clarifying the queries. The sample was distributed according to the variables of the study as shown in Table 1 below.

Table 1. Frequency and Percentages according to the study variables

\begin{tabular}{lccc}
\hline & Categories & Frequency & Ratio \\
\hline \multirow{2}{*}{ Gender } & Male & 36 & 43.4 \\
& Female & 47 & 56.6 \\
\multirow{3}{*}{ Qualification } & Higher deploma & 35 & 42.2 \\
& Bachelor & 36 & 43.4 \\
& Higher studies & 12 & 14.5 \\
Experience & Less than 5 years & 36 & 43.4 \\
& From 5-10 years & 12 & 14.5 \\
& More than 10 years & 35 & 42.2 \\
& Total & 83 & 100.0 \\
\hline
\end{tabular}

\subsection{The Study Tool}

The researcher studied a number of previous studies and the theoretical literature related to visual organizations, as well as his teaching experience in designing the study tools to find out the reality of the use of resource room teachers in the resource rooms to teach students with learning disabilities and to investigate the difficulties facing this use. The first questionnaire consisted of (16) items and the second included (12) items, the five-digit Likert scale was adopted to correct the degree of use of the resource room teachers for the visual organizations by giving each item of the questionnaire one degree (always, often, sometimes, rarely, never) which are represented digitally (5.4.3.2.1) respectively, the triple Likert scale was adopted to correct the difficulties encountered by the resource 
room teachers in the use of visual organizations by giving each item of the questionnaire one degree (always, often, rarely), which represents digitally $(3,2,1)$, respectively. The five and three-dimensional scales were adopted to analyze the results:

- Less than (2.33) low for the five-point scale and (1.00 - 1.66) low for the triple scale.

- From (2.33 to 3.66) medium for the five-point scale and (1.67 - 2.33) medium for the triple scale.

- $\quad$ From (3.66) and above high for the five-point scale and from (2.34 - 0.3) high for the triple scale.

\subsubsection{Construct Validity: Utilization}

In order to extract the indications of construct validity of the utilization scale, it was presented to a group of specialized arbitrators from the faculty members of Yarmouk University, based on the opinion of the arbitrators on the suitability of the tool for the study objectives, the required modifications were made until they were finalized to 16 items to identify the extent to which teachers of learning resource rooms used visual organizations to teach students with learning disabilities.

In terms of the validity of the internal consistency of the tool items, the correlation coefficients of the scale items with the total score were extracted in a pilot sample from outside the study members, consisting of (20) teachers. The correlation coefficient here is a sign of validity for each item in the form of correlation coefficient between each item and Overall score, the correlation coefficients of the items with the instrument as a whole ranged from 0.35 to 0.80 , and Table 2 shows this.

Table 2. Correlation coefficients between items and total score

\begin{tabular}{lccccc}
\hline Item & Correlation coefficient with the tool & Item & Correlation coefficient with the tool & Item & Correlation coefficient with the tool \\
\hline 1 & $0.48^{*}$ & 7 & $0.43^{*}$ & 13 & $0.80(* *)$ \\
2 & $0.48^{*}$ & 8 & $0.57(* *)$ & 14 & $0.58(* *)$ \\
3 & $0.35^{*}$ & 9 & $0.74(* *)$ & 15 & $0.73(* *)$ \\
4 & $0.80(* *)$ & 10 & $0.80(* *)$ & 16 & $0.75(* *)$ \\
5 & $0.78(* *)$ & 11 & $0.61(* *)$ & & \\
6 & $0.70(* *)$ & 12 & $0.69(* *)$ & & \\
\hline
\end{tabular}

* Statistically significant at the level of significance $(0.05)$.

** Statistically significant at the level of significance $(0.01)$.

It should be noted that all correlation coefficients were of acceptable level and statistically significant, so none of these items were deleted.

\subsubsection{Construct Validity}

To extract the signs of the construct validity of the scale of difficulties, it was presented to a group of specialized arbitrators from the faculty members from Yarmouk University, based on the opinion of the arbitrators on the suitability of the tool for the study objectives, the required amendments were made to finalize (12) items to identify the difficulties that limit the use of visual organizations by the teachers of the resource rooms.

In terms of the validity of the internal consistency of the tool items, the correlation coefficients of the items of the scale with the total score in a sample survey from outside the sample of the study consisted of (20) teachers were extracted. The correlation coefficient here represents the validity of each item in the form of correlation coefficient between each item and the total score of the tool (questionnaire). The correlation coefficients of the items with the tool as a whole ranged from 0.59 to 0.89 , and Table 3 shows this. 
Table 3. Correlation coefficients between items and total score

\begin{tabular}{lccccc}
\hline Item & $\begin{array}{c}\text { Correlation } \\
\text { coefficient with } \\
\text { the tool }\end{array}$ & Item & $\begin{array}{c}\text { Correlation } \\
\text { coefficient with } \\
\text { the tool }\end{array}$ & Item & $\begin{array}{c}\text { Correlation } \\
\text { coefficient with } \\
\text { the tool }\end{array}$ \\
\hline 1 & $0.77(* *)$ & 5 & $0.76\left(^{* *}\right)$ & 9 & $0.73(* *)$ \\
2 & $0.77(* *)$ & 6 & $0.86(* *)$ & 10 & $0.59(* *)$ \\
3 & $0.76(* *)$ & 7 & $0.60(* *)$ & 11 & $0.86\left(^{* *}\right)$ \\
4 & $0.73(* *)$ & 8 & $0.79(* *)$ & 12 & $0.89(* *)$ \\
\hline
\end{tabular}

* Statistically significant at the level (0.05).

** Statistical significant at the level of significance $(0.01)$.

It should be noted that all correlation coefficients were of acceptable level statistically significant, so none of these items were deleted.

\subsubsection{Reliability of the Study Tools}

To verify the reliability of the study tools (use and difficulties), the test-retest was verified by the application of the scale and re applied it two weeks later to a group outside the study sample consisted of (20) teachers. Pearson correlation coefficient was then calculated between their estimates at both times.

The coefficient of consistency was also calculated in the internal consistency method according to the Kronbach alpha equation, Table 4 shows the coefficient of internal consistency according to the Alpha Kronbach formula and the regression coefficients, these values are considered suitable for the purposes of this study. Table (4) shows the Test-Retest Reliability and internal consistency.

Table 4. Kronbach alpha consistency coefficient and test/retest of the domains and the total score

\begin{tabular}{ccc}
\hline Domain & Test/retest & Internal consistency \\
\hline Usage & 0.91 & 0.87 \\
Obstacles & 0.88 & 0.85 \\
\hline
\end{tabular}

- The tool was distributed to male and female teachers in the schools in person where the source rooms were located. The distribution rate was one questionnaire on the most formal working day to discuss the teacher, visit the resource room and answer the questions about clarifying and filling some of the items in the tool.

- The tool has been emptied and analyzed to determine the effect of the following variables: qualification, years of experience, and training courses on the use of resource room teachers for visual organizations for students with learning disabilities using the SPSS program to produce the following results.

\section{Results of the Study}

Question One: What is the degree to which teachers of the learning resource rooms use visual organizations to teach students with learning disabilities?

To answer this question, arithmetical means and standard deviations were extracted to the extent to which educational resource room teachers use visual organizations to teach students with learning disabilities. The table below illustrates this. 
Table 5. The arithmetical means and the standard deviations of the items of the extent of the use of educational resource room teachers for visual organizations in teaching students with learning disabilities are arranged in descending order by arithmetical means

\begin{tabular}{|c|c|c|c|c|c|}
\hline $\begin{array}{c}\text { Rank } \\
(*)\end{array}$ & $\mathrm{N}(*)$ & Items & Mean & $\begin{array}{l}\text { Standard } \\
\text { deviation }\end{array}$ & Degree \\
\hline 1 & 12 & Use art forms (to illustrate similarities and differences in concepts) & 2.66 & .668 & Moderate \\
\hline 2 & 13 & $\begin{array}{l}\text { Use comparative concept maps (to chart comparison tables between } \\
\text { concepts such as lettering s, d, r, z) }\end{array}$ & 2.63 & .776 & Moderate \\
\hline 3 & 5 & $\begin{array}{l}\text { Use the Analysis Map (to understand the relationships between the } \\
\text { whole and the part) }\end{array}$ & 2.61 & .794 & Moderate \\
\hline 4 & 4 & $\begin{array}{l}\text { Use the tree map (organizing and classifying a more general theme } \\
\text { to the most private and familiar to students) }\end{array}$ & 2.60 & .795 & Moderate \\
\hline 5 & 10 & $\begin{array}{l}\text { Use hierarchical maps (to sort the lesson by title, then branch and } \\
\text { sub-sections, descending or ascending) }\end{array}$ & 2.54 & .845 & Moderate \\
\hline 6 & 15 & $\begin{array}{l}\text { Use the timeline organizer (for chronological order and explain the } \\
\text { causes and results such as the order of the weekdays, Sunday.. } \\
\text { Monday.. Tuesday ...... etc }\end{array}$ & 2.54 & .831 & Moderate \\
\hline 7 & 11 & Use loop maps (for sequence of lesson events) & 2.37 & .933 & Moderate \\
\hline 8 & 16 & Use Sequential ring charts (for stages and evolution) & 2.27 & .964 & low \\
\hline 9 & 6 & $\begin{array}{l}\text { Use the blurry flow map (browse the information, explain the } \\
\text { sequence and practical steps) }\end{array}$ & 2.04 & 1.005 & Low \\
\hline 10 & 1 & $\begin{array}{l}\text { Use pie charts as a definition of concepts (introduction to definition } \\
\text { and clarification of idea) }\end{array}$ & 1.90 & .983 & Low \\
\hline 11 & 8 & Use web maps (to explain and clarify) & 1.87 & .997 & Low \\
\hline 12 & 3 & $\begin{array}{l}\text { Use the double comparative bubbles to compare two topics, such as } \\
\text { letter and word segments }\end{array}$ & 1.84 & .994 & Low \\
\hline 13 & 9 & Use flowing maps (to describe the sequence) & 1.84 & .994 & Low \\
\hline 14 & 14 & $\begin{array}{l}\text { Use the Qantara map (to illustrate the similarities and relationships } \\
\text { between elements of the material) }\end{array}$ & 1.58 & .912 & Low \\
\hline 15 & 7 & $\begin{array}{l}\text { Use multiple flow maps (to explain and clarify the relationship } \\
\text { between cause and effect) }\end{array}$ & 1.55 & .901 & Low \\
\hline 16 & 2 & $\begin{array}{l}\text { Use the wide bubble map (to describe qualities, objects, and } \\
\text { properties) }\end{array}$ & 1.27 & .682 & Low \\
\hline All & Items & The usage & 2.13 & .448 & Low \\
\hline
\end{tabular}

Refer to the rank of the items that the members of the study estimated descending.

* Indicates the sequence of items as appeared in the questionnaire distributed to the study members.

Table 5 shows that the mathematical means ranged between 2.27 and 2.66, where item 12, which states that "the use of art forms (to illustrate the similarities and differences in concepts)" came in first rank with a mean of 2.66, While item (2), which states "Use the wide bubble map (to describe qualities, objects and characteristics"), came last with a mean of 1.27 . The overall arithmetic mean for the domain as a whole was 2.13 with a low degree.

This was due to the items $12,13,5,4,10,15$, and 11, which had a medium degree of use ranging between 2.37 and 2.66 due to the existence of models and examples in some syllabuses and the availability of methods and possibilities within the resource room, allowing resource room teachers to use them in appropriate learning situations.

Relating to the items $16,8,8,3,9,14,7$, and 2 , the degree of use was low and ranged between (1.27-2.27) due to the absence of illustrative examples in the curriculum, and therefore the teacher's lack of concept to use this strategy as one of the teaching methods within the resource rooms, and possibly because they are not available in the resource rooms.

Question Two: What are the difficulties facing resource room teachers in the use of visual organizations?

To answer this question, the arithmetical means and standard deviations of the difficulties faced by resource room teachers in the use of visual organizations were extracted, and the table below illustrates this. 
Table 6. The arithmetical means and the standard deviations of the items of difficulties facing the resource room teachers in the use of visual organizations are arranged in descending order according to the arithmetic means

\begin{tabular}{|c|c|c|c|c|c|}
\hline Rank & $\mathrm{N}$ & Items & Mean & $\begin{array}{l}\text { Standard } \\
\text { deviation }\end{array}$ & Degree \\
\hline 1 & 12 & $\begin{array}{l}\text { Parents do not follow their children with educational } \\
\text { difficulties to complete the educational programs that rely } \\
\text { on the visual organizations within the resource room. }\end{array}$ & 2.93 & .304 & High \\
\hline 2 & 11 & $\begin{array}{l}\text { Failure to prepare the resource room and provide it with } \\
\text { the necessary modern tools and techniques }\end{array}$ & 2.90 & .370 & High \\
\hline 3 & 8 & $\begin{array}{l}\text { Interaction between teachers of learning resource rooms } \\
\text { and teachers of other materials is limited, which is } \\
\text { reflected in the effectiveness of using the strategies of } \\
\text { visual organizations and students with learning disabilities }\end{array}$ & 2.89 & .442 & High \\
\hline 4 & 7 & $\begin{array}{l}\text { Visual organizations need more time and effort than } \\
\text { conventional methods, especially when using the required } \\
\text { capabilities }\end{array}$ & 2.87 & .463 & High \\
\hline 5 & 9 & $\begin{array}{l}\text { Lack of sufficient professional development programs for } \\
\text { resource room teachers to use teaching strategies in visual } \\
\text { organizations }\end{array}$ & 2.87 & .435 & High \\
\hline 6 & 6 & $\begin{array}{l}\text { Training and teaching programs do not take into account } \\
\text { the individual differences between students with learning } \\
\text { disabilities using visual organizations }\end{array}$ & 2.83 & .514 & High \\
\hline 7 & 5 & $\begin{array}{l}\text { Inadequate of resource rooms for the design and use of } \\
\text { software and mapping of visual organizations }\end{array}$ & 2.82 & .521 & High \\
\hline 8 & 2 & $\begin{array}{l}\text { Lack of interest of the school administration in the } \\
\text { technical aspects of the learning resource rooms to teach } \\
\text { students with learning difficulties }\end{array}$ & 2.69 & .731 & High \\
\hline 9 & 4 & $\begin{array}{l}\text { Incompatibility between the resource rooms and } \\
\text { classrooms in teaching students with learning difficulties } \\
\text { using the strategy of visual organizations }\end{array}$ & 2.69 & .731 & High \\
\hline 10 & 10 & $\begin{array}{l}\text { Inadequate strategies of visual organizations for the target } \\
\text { age group in the resource room }\end{array}$ & 2.43 & .900 & High \\
\hline 11 & 1 & $\begin{array}{l}\text { Lack of a clear strategy for selecting students with learning } \\
\text { difficulties }\end{array}$ & 2.42 & .912 & High \\
\hline 12 & 3 & $\begin{array}{l}\text { The limited experience of teachers of educational resource } \\
\text { rooms in teaching programs for students with learning } \\
\text { difficulties using the strategy of visual organizations }\end{array}$ & 2.16 & .994 & Medium \\
\hline $\begin{array}{c}\text { All } \\
\text { items }\end{array}$ & & Difficulties & 2.77 & .234 & High \\
\hline
\end{tabular}

Table 6 shows that the mathematical means ranged between 2.16 and 2.93, where items 12, which states that "parents do not follow up their children with educational difficulties to complete the educational programs that rely on the visual organizations within the resource room" came in the first rank with a mean of 2.93, while item 3, which states "The limited experience of teachers of educational resource rooms in teaching programs of students with learning difficulties using the strategy of visual organizations" came last with a mean of 2.16. The overall mean of the domain as a whole reached 2.77 with a high degree. This means that all the items of difficulties identified by the study subjects were rated with a high degree of difficulty, except for one item which was estimated to be medium, which is related to the teachers' experience in teaching students with learning disabilities.

These results are attributed to the reality of the situation in the resource rooms and the difficulties and challenges faced by the teachers of those rooms, which are put upon the supervisor of these rooms in terms of equipment and training and laying the foundations that regulate and organize the work of these rooms to achieve the greatest possible benefit to support the education process within the vision and philosophy of the supervisor, and not only to find rooms for sources and provide a teacher and the absence of equipment and / or modernization of those educational and technical equipment and it seems that some teachers have medium skill in teaching resulting from training and rehabilitation and / or teaching time. 
Question Three: Are there any statistically significant differences $(\alpha=0.05)$ in the degree of using visual organizations in teaching students with learning disabilities due to gender, scientific qualification and years of experience variables?

To answer this question, the arithmetical means and standard deviations of the degree of use of teaching resource room teachers for visual organizations in teaching students with learning difficulties according to gender, scientific qualification, and years of experience variables were extracted and the table below shows this.

Table 7. Means and standard deviations of the degree of use of educational resource room teachers for visual organizations in teaching students with learning difficulties according to gender, scientific qualification, and years of experience variables

\begin{tabular}{ccccc}
\hline & Variable & Mean & Standard deviation & N \\
\hline \multirow{2}{*}{ Gender } & Male & 2.27 & .309 & 36 \\
& Female & 2.03 & .509 & 47 \\
Scientific & Higher Diploma & 2.26 & .260 & 35 \\
qualification & Bachelor & 1.95 & .584 & 36 \\
& Postgraduate & 2.32 & .078 & 12 \\
Experience & Less than 5 years & 2.02 & .585 & 36 \\
& From 5-10 years & 2.19 & .257 & 12 \\
& More than 10 years & 2.23 & .290 & 35 \\
\hline
\end{tabular}

Table 7 shows an apparent discrepancy in the arithmetical means and standard deviations of the degree of use of educational resource room teachers for visual organizations in teaching students with learning difficulties due to different categories of gender, qualifications and years of experience variables. To illustrate the significance of the statistical differences between the arithmetic means, a triangular variance analysis was used. Table 8 shows this.

Table 8. Analysis of the triangular variation of the impact of gender, qualification and years of experience variables on the degree of use of educational resource room teachers for visual organizations in teaching students with learning disabilities

\begin{tabular}{cccccc}
\hline Source of variance & Sum of squares & Df & Mean of squares & F value & Sig \\
\hline Gender & 2.047 & 1 & 2.047 & 14.051 & .000 \\
Scientific qualification & 3.354 & 2 & 1.677 & 11.509 & .000 \\
Years of experience & 2.367 & 2 & 1.184 & 8.124 & .001 \\
Error & 11.219 & 77 & .146 & & \\
Total & 16.433 & 82 & & & \\
\hline
\end{tabular}

Table 8 shows the following:

- There were statistically significant differences $(\alpha=0.05)$ due to gender impact, with a value of 14.051 and a statistical significance of 0.000 . Differences came in favor of males. It seems that males have been more knowledgeable, tolerant and patient in teaching students with learning difficulties using visual organizations than females.

- There were statistically significant differences $(\alpha=0.05)$ due to the effect of the scientific qualification, with a value of 11.509 and a statistically significant value of 0.000 . To show statistically significant differences between the arithmetic means, the post comparisons were used in the same way as shown in Table 9.

Table 9. Dimensional comparisons of the effect of the academic qualification on the degree of use of educational resource room teachers for visual organizations in teaching students with learning disabilities

\begin{tabular}{cccccc}
\hline & Mean & Higher diploma & Bachelor & Posgraduate \\
\cline { 2 - 6 } Higher Diploma & 2.26 & & & \\
Bachelor & 1.95 & $.30^{*}$ & & \\
Postgraduate & 2.32 & .06 & $.37^{*}$ & \\
\hline
\end{tabular}

* Significant at the level $(\alpha=0.05)$. 
Table 9 shows that there are statistically significant differences $(\alpha=0.05)$ between BA on the one hand and high diploma and higher studies on the other hand. The researcher explains these results that the teachers of the resource rooms of high diploma and higher studies are basically teachers with a great knowledge and specialization in teaching students with learning disabilities better than teachers with a bachelor's degree using educational techniques of different types, traditional or contemporary, such as visual organizations.

There were statistically significant differences $(\alpha=0.05)$ due to the effect of the years of experience, with a value of 8.124 and statistical significance of 0.001 , to show the statistically significant differences between the arithmetic means, the post comparisons were used in the same way as shown in Table 10.

Table 10. Scheffe post hoc comparisons to the effect of years of experience on the degree of use of educational resource room teachers for visual organizations in teaching students with learning disabilities

\begin{tabular}{ccccc}
\hline & Mean & Less than 5 years & From 5-10 years & More than 10 years \\
\hline Less than 5 years & 2.02 & & & \\
From 5-10 years & 2.19 & .17 & & \\
More than 10 years & 2.23 & $.22 *$ & .05 & \\
\hline
\end{tabular}

* Significant at the level $(\alpha=0.05)$.

Table 10 shows that there are statistically significant differences $(\alpha=0.05)$ between less than 5 years and more than 10 years. The differences were in favor of more than 10 years. This is due to the fact that teachers with long teaching experience are likely to be more efficient than those with little or no recent experience in teaching students with learning disabilities.

\subsection{Recommendations}

At the conclusion of this study, the researcher believes that there are some recommendations in order to optimize the use of the source rooms:

1) Expand the training of teachers in the use of strategies that raise and improve the level of learning process using visual organizations in teaching and producing it using training programs in this field.

2) Increase the support provided to the source rooms by the technical equipment and modern means to facilitate the design and use of visual organizations and the need for periodic maintenance of the devices.

3) Create channels of communication between teachers and parents in cooperation to raise the academic level of their children.

4) Taking into account in the amendment of the curriculum the need to introduce modern strategies, especially the visual organizations that support the learning process.

5) Conduct similar studies in the future to identify the extent to which resource rooms have developed.

\section{References}

Abed, W. (2012). Satisfaction of parents of students with learning difficulties about the services provided to them in the resource rooms. Journal of Administrative and Human Sciences, University of Majmaa, 1.

Abo Nayan, I. (2001). Learning Difficulties Teaching Methods and Cognitive Strategies (1st ed.). Riyadh, Academy of Special Education

Al Farhan, A. (2008). The Theory of Ozbl in Verbal Learning of Meaning. Retrieved from http://www.watfa.net/studr8.htm

Al-Qasim,W. (2012). Teaching Strategy using Concept Maps. Teaching Strategies Development Project in the Holy Capital, Saudi Arabia. Retrieved from https://www.bishaedu.gov.sa/vb/attachment.php?attachmentid

Attia, M. (2008). Modern Strategies in Effective Teaching (1st ed.). Dar Al-Safa for Publishing and Distribution, Amman-Jordan

Ausubel, D. (1993). The Psychology of Meaningful Learning. NewYork, Gune and Stratton.

Badawi, M. (2004). A comparative study of the skills of using images and illustrations of social studies among students in the basic stage. Journal of Faculty of Education, 33.

Baiyun, C. (2007). Effects of Advance Organizers on Learning and Retention from A fully Web-Based Class (Doctoral Dissertation). Retrieved from http:// www.etd.fcla.edu/CF/CFE0001556/Chen_Baiyun_200705 
Balawi, M. (2014). The Effect of Illustrative Strategy on Improving Understanding among Students with Learning Disabilities (Unpublished master thesis). Irbid, Jordan.

Batayneh et al. (2007). Learning Difficulties in Theory and Practice (2nd ed.). Amman, Dar al-Masirah

Dwyer, F., \& Moore, D. (1994). Visual Literacy: A Spectrum of Visual Learning Educational Technology. New Jersey, Englewood Cliffs pub. Inc.

Dye, G. (2000). Graphic organizers to the rescue, helping students link and remember information. Teaching Exceptional Children, 32(30), 72-76. https://doi.org/10.1177/004005990003200311

Ellis, E. (2001). Makes sense strategies: connecting teaching learning and assessment (computer software). Tuscaloosa, Al: Masterminds Publishing

Humbert, R. (2014). The Effectiveness of Graphic Organizers: A Quantitative Study on The Effect of Venn Diagrams Versus Concept Maps on Student Test Scores (Master thesis). Retrieved from https://dspace.sunyconnect.suny.edu.edu/bitstream/handle/1951/64562

Hussein, Kh. \& Ahmad, Z. (2016). The impact of the use of visual organizations' strategies in the visual thinking skills among the fourth grade students in chemistry. Lark for Philosophy, Linguistics and Social Sciences, 21st Issue.

Husseini, D. (2000). Effectiveness of the strategies of learning by discovery and visual organizations in the achievement of secondary school students in Islamic Education in the State of Kuwait (Master thesis, Amman Arab University for Graduate Studies

Hyerle, D. (1995). Thinking Maps: Seeing is Understanding. Educational Leadership, 53(4), 85-89.

Kirkland, E. C., \& Others (1995). Using Advance Organizers with Learning Disabled Students PDF. Review of Educational Research, 61(2).

Lee H. (2007). The use of animation as a tool for concept learning. Dai Forum. Retrieved from https://www.moe.gov.om/showthread.php

Macarthur, C. (2001). Technology Applications for Students with Literacy Problems. Elementary School Journal.

Miranda, J. (2011). Effect of Graphic Organizers on the reading comprehension of an English Language Learner with a Learning Disability. Second Language Studies, 30, 95-183. Retrieved from http://www.hawaii.edu/sls

Nabhan, Y. (2008). Teaching Skills. Al Yazoudi Scientific Publishing House, Amman-Jordan

Novak, J. D., \& Gowin, D. B. (1984). Learning how to learn. Cambridge, Cambridge university press. https://doi.org/10.1017/CBO9781139173469

Oleary, M. (1995). The use of concept maps As Advance Organizers in grade seven science (MA, Saint Mary's University, Dissertation Abstract International 33/02, p. 304).

Rahili, S. (2014). The reality of using special education teachers for visual organizations in teaching students with learning difficulties in integrated schools in Medina (Master thesis, Yarmouk University).

Rober, R. (2006). Using Technology to Teach Students with Mild Disabilities: Current Trends and Future Technologies. Elementary General Education, Senior, Indiana University, Law \& Disorder, 1.

Sharif, G. (2011). The Effect of Using Concept Maps on Achievement and Adjustment of Shortages and Attention of Special Education Students. Journal of the College of Basic Education, 11(2).

Teacher's Letter. (1987). National Conference for Educational Development. A summary of the work of the National Committee to discuss the recommendations, publications of the Ministry of Education, Amman.

Waqfi, R. (1996). Educational Strategies in Learning Difficulties. Amman:Princess Tharwat College

Waqfi, R. (2009). Theoretical and Applied Learning Difficulties (1st ed.). Amman, Dar al-Masirah.

Zaghloul, I. (2001). Principles of Educational Psychology (1st ed.). University Book House.

\section{Copyrights}

Copyright for this article is retained by the author(s), with first publication rights granted to the journal.

This is an open-access article distributed under the terms and conditions of the Creative Commons Attribution license (http://creativecommons.org/licenses/by/4.0/). 